\title{
5 \\ DUE DILIGENCE FOR NEW APPOINTMENTS AND NEW DIRECTORS
}

\author{
Charlotte Valeur
}

Conducting due diligence for board members should be seen from two different angles. A new board member should conduct due diligence on the organisation, its executive and the board members before taking on a new appointment. The board/organisation should conduct due diligence on any new board member before appointing them.

\section{New appointment}

The potential risks of joining a board are ever increasing, and any candidate should conduct appropriate due diligence before accepting a new position. The process of conducting due diligence will enable the candidate to determine whether or not they will add value to the board, assess the level of risk within the appointment and identify potential conflicts of interest. 
The first level of due diligence is to research any public information, annual accounts and news articles, recent and historical, about the organisation, its leadership and reputation. The candidate should also ask about the financial plans and budgets, and information about any litigation filed. Ideally, minutes should be reviewed together with the agendas and board packs from the last one to two years. This can usually be carried out under a non-disclosure agreement to protect any confidentialities.

Any board candidate should also look into the board composition and background of the current directors. It is worth also looking into: How were they identified and appointed? What is their reputation? Do they have any conflicts of interest? Do they have any personal relationships with other board members or the executives?

Most information will be available publicly, and the rest should be obtained directly from the organisation through the interview process and the relevant papers. This due diligence makes it possible for the prospective director to assess the potential risks associated with being a director of the organisation. It can also reveal which main areas will require extra time and input from the board members.

\section{Questions to ask about the organisation}

\section{Financial}

- What do the public documents reveal about the current and historical state of the finances?

- What is the future expected to bring?

\section{Insurance}

- What is the $\mathrm{D} \& \mathrm{O}$ insurance coverage and is it adequate?

- Does the organisation have adequate insurances in place covering all aspects of the business?

- Have there been any claims or notifications during the last ten years?

\section{Legal and regulatory}

- What is the legal entity of the organisation? 
- Is the organisation carrying out any regulated activity? If so, what activity and what regulator is regulating it?

- Have there been any legal or regulatory breaches during the last ten years?

\section{Reputationally}

- What is the reputation of the organisation?

- How has reputation been managed historically?

- How is reputation being managed now?

\section{Culture}

- What is the culture of the organisation and the board?

- Can you support the culture and values of the organisation and its board?

- Can you stand behind the behaviours of the board and executives?

- What do the public comments/posts on social media tell you about the culture of the organisation?

\section{Governance}

- Does the organisation adhere to a specific code of corporate governance?

- If yes, which one?

- If no, why not?

- What do the historical books and records (minutes/agendas) reveal about governance and board dynamics?

- How frequently are board meetings being held, where and how (in person/on phone/online)?

- Is attendance by directors at meetings appropriate?

\section{Risk management}

- Does the organisation perform adequate risk management, so the board is able to discharge its duties with regards to risk oversight?

- How often is the risk register tabled to be discussed in board meetings?

- Does a risk-taking culture exist among executives? 


\section{Stakeholder engagement}

- Does the organisation have a stakeholder engagement and management plan in place?

- Are stakeholder communications appropriate and relevant?

- How engaged is the board in stakeholder management?

\section{Public statements/Press}

- What historical press has been published about the organisation?

- How is the organisation regarded by the press?

- How is the organisation spoken about on social media/online?

\section{Questions to ask about the board and board members}

- How were the current directors identified?

- What is the board composition in terms of experience, skills, gender, age, ethnicity, background, tenure?

- What are the areas of expertise and professional qualifications of existing board members?

- Do any of the directors serve on several boards together?

- Do any of the directors have any other business connections between them?

- Are the board members unified and aligned generally?

- Are there any current or historical relationships among board members?

- What is the board's relationship with stakeholders?

- Is there any historical press about individual board members?

- Are the director fees paid (if any) appropriate for the risk profile, liability and time commitment required of the role?

- Are the fees in line with fees of similar organisations?

\section{Questions to ask yourself}

- Do I have the necessary capacity to take on the appointment?

- Do I fully understand the time commitment involved with the engagement? 
- Do I understand the vision, mission, strategy and purpose of the organisation?

- Am I aligned with the purpose, values and culture of the organisation?

- Do I believe in the capabilities of the executives to execute the strategy?

- Do my specific skills and experience add value to the organisation and its board?

- Is the appointment letter clear about time commitment, D\&O insurance, termination and so on?

- Do I have any conflict of interests?

\section{New director}

Any board taking on a new director should conduct due diligence on the candidate to ensure they are fit and proper for the position. Individuals appointed as board members are often chosen for their breadth of experience in certain areas. They are expected to play a key role in providing an objective, independent and constructive view of how the executive team is performing. They also perform a valuable role in determining appropriate levels of executive remuneration and advice on succession planning. For these reasons, they need to be able to act independently and have an independent state of mind. They should be able to challenge and support executives freely and have an objective view on matters.

\section{Questions to ask of a prospective new director}

- Are they regulated as directors? If yes, under which regulations?

- What other commitments do they have?

- What other board appointments do they have?

- Are they financially dependent on the income from the appointment(s)?

- Do any of the appointments or commitments represent a conflict of interest with the organisation?

- Do they have any business, interests or personal connections material to the position?

- Do they have any conflict of interest with the business of the organisation?

- Do they have any interest in, or connections with, stakeholders of the organisation? 
- Can they give enough time to this appointment?

- What particular contribution do they bring to the board?

- Are they politically engaged? If so, how?

- Do they hold membership of any relevant professional body?

- Have they been convicted of any offence involving fraud or other dishonesty?

- Have they been convicted of any offence under any enactment relating to banking or other financial services, building societies, collective investment funds, companies (including insider dealing), consumer credit, consumer protection, credit unions, friendly societies, industrial and provident societies, insurance, insolvency or money laundering?

- Have they been convicted of an offence of perjury or conspiracy to pervert the course of justice?

- Have they been convicted of an offence in connection with, or in relation to taxation, for which a person aged 21 or over may have been sentenced to a term of two years or more?

- Have they been censured, disciplined, or criticised by any professional body to which they belong or have belonged?

- Are they the holder of a practicing certificate and have they surrendered it, had it revoked, withdrawn, or had conditions attached to it?

- Have they been censured, disciplined, or publicly criticised by, or made the subject of, a court order at the instigation of any regulatory authority?

- Have they been dismissed from any office, employment, fiduciary office, or position of trust, or barred from entry to any profession or occupation, whether or not remunerated, at any time in the last ten years?

- Have they ever been the subject of internal enquiry or suspended from office or asked to resign?

- Are they currently, or have they ever been, involved in any litigation or are they aware of any pending involvement in litigation? 